\title{
Desalination Concentrate Quantification and Management Through Multi-Stage Biomass Production: A Conceptual Framework for Further Research
}

\author{
Rahul Hampaul and Bhaskar Sen Gupta
}

\section{ABSTRACT}

\begin{abstract}
Global population growth and climate change are adding pressure on conventional water sources to meet the rising demand. Reliance on unconventional water sources utilizing desalination technologies is increasing to ensure water security. A major economic and environmental challenge in the sustainable adoption of desalination is the hypersaline concentrate that is generated as a byproduct. Brine quantification estimation process and disposal strategies along with the associated costs are provided. Brine re-use for biomass production offers a promising solution to help mitigate the environmental and economic challenges related to brine disposal. Soil salinization is a key issue with the land application of brine impacting its sustainability and applicability in the long run. The paper proposes a methodology for multi-stage biomass production using desalination brine. Added advantage of the proposed methodology is the potential to manage soil salinization, adopt sustainable agricultural practices such as crop rotation and enhancing biodiversity through inclusion of marshlands and wetlands as part of the brine disposal strategy. The paper also proposes an experimental setup for lab scale experimentation and identifies research priorities and provides recommendations for further evaluation.
\end{abstract}

Published Online: May 11, 2021

ISSN: $2684-446 \mathrm{X}$

DOI :10.24018/ejgeo.2021.2.3.135

Rahul Hampaul*

Independent Researcher, Nanaimo, British Columbia, Canada.

(e-mail: rahulhampaul@gmail.com)

\section{Bhaskar Sen Gupta}

School of Energy, Geoscience, Infrastructure and Society, Heriot-Watt University, Water Academy, United Kingdom.

(e-mail: B.SenGupta@@hw.ac.uk)

Keywords: Climate adaptation, climate emergency, brine management, halophyte, macroalgae, reject brine.

\section{INTRODUCTION}

According to the United Nations projections the world population in 2050 will grow to 9.8 billion and increase to 11.2 billion in 2100 [1]. Water and food security are the two critical challenges that humanity will face, made worse by the climate emergency. The impacts will be unevenly distributed across the globe making the economically disadvantaged population most vulnerable [2]. Sustainable Developmental Goal number 6 (SDG 6) adopted by all United Nations member aims to ensure availability and sustainable management of water and sanitation for all [3]. Currently according to some estimates $40 \%$ of the global population faces severe water scarcity which is expected to rise to $60 \%$ by 2025 [4]. Increased water consumption due to rising standard of living, industrial growth and precipitation irregularities due to climate change are further worsening the issue of water scarcity [5], [6]. The water and food security risk can be diversified by tapping into unconventional resources once water conservation and reliance on conventional sources of water have reached their sustainable utilization limits. These factors position desalination on a high growth trajectory as a reliable tool for tapping into utilization of unconventional water. However, high energy consumption and unsustainable brine management are challenges associated with the adaptation of desalination technologies. Industry has come a long way in addressing some of these issues by improving energy efficiency and integrating renewable energy [7]. Current paper focuses on brine management by re-use application such as land application and biomass production as a means of enhancing sustainability, minimizing environmental damage and help diversify food security issues. According to some estimates in order to meet the food security needs of population growth of up to 9.7 billion in the next three decades the food production needs to increase by up to $70 \%$ by 2050 [8]. The situation becomes more dire with the realization that some of the most agriculturally productive areas will suffer from soil salinization and flooding due to the impact of the climate emergency [9], [10]. An attempt is made in this paper to identify synergies that exist between sustainable brine management through land application and potential for biomass production that can be of economic value such as fodder or for human consumption. Methodology for the estimation of brine production by various desalination technologies is provided. A summary of the desalination brine disposal methods and associated costs is included. A novel approach of brine management with multi-stage biomass production is proposed which could potentially help in managing soil salinity, facilitate adoption of sustainable cultivation practices such as vegetation rotation and enhance biodiversity in the disposal area. An experimental set up for further research and experimentation to bridge data gaps of 
the proposed approach is recommended.

\section{REJECT BRINE GENERATION}

Desalination process separates feedwater into two streamsproduct water and waste stream also known as reject brine or concentrate. Fig. 1 shows the waste streams generated during desalination process using reverse osmosis [11].
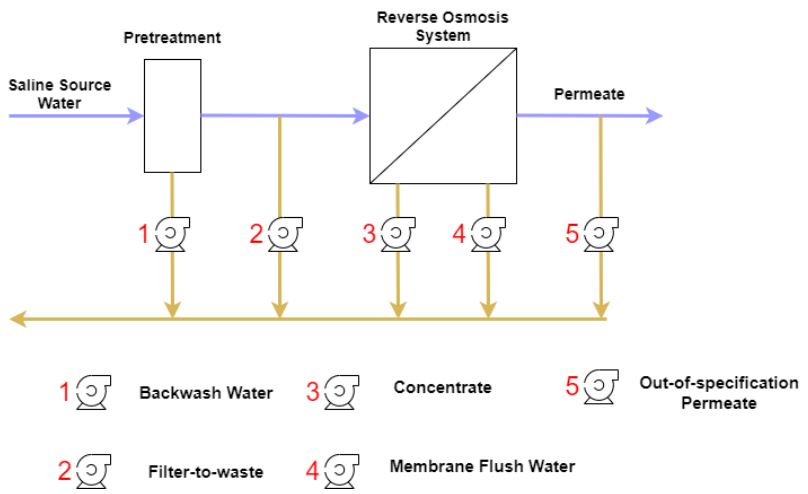

Fig. 1. Discharge streams of a typical desalination process utilizing reverse osmosis.

Feed water recovery from a desalination process is determined by calculating recovery ratio $(\mathrm{R})$ using following formula [12].

$R=\frac{Q_{P}}{Q_{F}}=\frac{Q_{P}}{Q_{C}+Q_{F}}$

where $\mathrm{Q}_{\mathrm{p}}$ is the product flow rate, $\mathrm{Q}_{\mathrm{f}}$ is the feed flow and $\mathrm{Q}_{\mathrm{c}}$ is the concentrate flow rate. The recovery ratio will vary based on desalination technology implemented and its operational philosophy. For example, the recovery ratio for the desalination plant utilizing reverse osmosis could vary based on the type of filtration membrane utilized, number of membrane elements in each vessel, pre-treatment and stages per permeate pass [11].

Strength of the concentrate is determined by total dissolved solids (TDS) and conductivity. Once the recovery rate is known using equation (1), a theoretical TDS concentration of the brine can be calculate using following equation:

$T D S_{\text {concentrate }}=T D S_{\text {feed }}\left(\frac{1}{1-R}\right)-\frac{R \times T D S_{\text {permeate }}}{100(1-R)}$

As the value of $\operatorname{TDS}_{\text {permeate }}$ is very low, it can be approximated as zero and (2) can be converted to (3):

$T D S_{\text {concentrate }}=T D S_{\text {feed }}(1 / 1-R)$

From (3) concentration factor (CF) is derived as per (4):

$C F=\frac{T D S_{\text {concentrate }}}{T D S_{\text {feed }}}=\left(\frac{1}{1-R}\right)$

Calculated theoretical recovery ratios (RR) and concentration factors $(\mathrm{CF})$ for six different desalination technology types treating six different types of feedwater seawater $(\mathrm{SW})$, brackish water $(\mathrm{BW})$, river $(\mathrm{RW})$, pure water $(\mathrm{PW})$, brine (BR) and wastewater (WW) is presented in Table I. Once the concentration factor is known a theoretical TDS concentration of brine can be calculated. Table II provides calculated TDS range of brine produced by treatment of brackish water with a TDS range of 3000-20,000 mg/l [6].

TABLE I: THEORETICAL RECOVERY RATIOS (RR) AND CONCENTRATION FACTOR (CF) FOR DIFFERENT DESALINATION TECHNOLOGIES AND FEEDWATER COMBINATION [6]

\begin{tabular}{cccccccc}
\hline \multirow{2}{*}{ Type } & & \multicolumn{7}{c}{ Feedwater Type } \\
\cline { 3 - 8 } & & $S W$ & $B W$ & $R W$ & $P W$ & $B R$ & $W W$ \\
\hline Reverse & $\mathrm{RR}$ & 0.42 & 0.65 & 0.81 & 0.86 & 0.19 & 0.65 \\
Osmosis (RO) & $\mathrm{CF}$ & 1.72 & 2.86 & 5.26 & 7.14 & 1.23 & 2.86 \\
Multi Stage & $\mathrm{RR}$ & 0.22 & 0.33 & & 0.35 & 0.09 & 0.33 \\
Flash (MSF) & $\mathrm{CF}$ & 1.28 & 1.49 & 1.00 & 1.54 & 1.10 & 1.49 \\
Multiple Effect & $\mathrm{RR}$ & 0.25 & 0.34 & 0.35 & & 0.12 & 0.34 \\
Desalination & $\mathrm{CF}$ & 1.33 & 1.52 & 1.54 & 1.00 & 1.14 & 1.52 \\
(MED) & & & & & \\
Nano Filtration & $\mathrm{RR}$ & 0.69 & 0.83 & 0.86 & 0.89 & & 0.83 \\
(NF) & $\mathrm{CF}$ & 3.23 & 5.88 & 7.14 & 9.09 & 1.00 & 5.88 \\
Electrodialysis & $\mathrm{RR}$ & 0.86 & 0.90 & 0.90 & 0.90 & 0.85 & 0.90 \\
(ED) & $\mathrm{CF}$ & 7.14 & 10.00 & 10.00 & 10.00 & 6.67 & 10.00 \\
Electrodeioni- & $\mathrm{RR}$ & 0.9 & 0.97 & 0.97 & 0.97 & & 0.97 \\
zation (EDI) & $\mathrm{CF}$ & 10 & 33.33 & 33.33 & 33.33 & 1.00 & 33.33 \\
\hline
\end{tabular}

TABLE II: CALCULATED CONCENTRATION OF THE CONCENTRATE FOR DIFFERENT DESALINATION TECHNOLOGIES APPLIED TO BRACKISH WATER

\begin{tabular}{ccccccc}
\hline \multirow{2}{*}{$\begin{array}{c}\text { Desalination } \\
\text { Type }\end{array}$} & \multicolumn{2}{c}{ Feedwater $(\mathrm{mg} / \mathrm{l})$} & & \multicolumn{2}{c}{ Concentrate $(\mathrm{mg} / \mathrm{l})$} \\
\cline { 2 - 3 } \cline { 5 - 6 } & $\begin{array}{c}\text { Lower } \\
\text { Limit }\end{array}$ & $\begin{array}{c}\text { Upper } \\
\text { Limit }\end{array}$ & CF & & $\begin{array}{c}\text { Lower } \\
\text { Limit }\end{array}$ & $\begin{array}{c}\text { Upper } \\
\text { Limit }\end{array}$ \\
\hline RO & & & 2.86 & 8580 & 57200 \\
MSF & & & 1.49 & 4470 & 29800 \\
MED & \multirow{2}{*}{3000} & 20,000 & 1.52 & 4560 & 30400 \\
NF & & & 5.88 & 17640 & 117600 \\
ED & & & 10 & 30000 & 200000 \\
EDI & & & 33.33 & 99990 & 666600 \\
\hline
\end{tabular}

TABLE III: GLOBAL BRINE PRODUCTION AND CATEGORIZATION BY GEOGRAPHICAL AREA, INCOME LEVEL AND SECTOR USE [6]

\begin{tabular}{ccc}
\hline Criterion & $\begin{array}{c}\text { Brine Production } \\
\text { (Million } \mathrm{m}^{3} / \text { day) }\end{array}$ & Percentage (\%) \\
\hline Global & $\begin{array}{c}141.5 \\
\text { Geographical region }\end{array}$ & 100 \\
Middle East \& North Africa & 99.4 & 70.3 \\
East Asia \& Pacific & 14.9 & 10.5 \\
North America & 5.6 & 3.9 \\
Western Europe & 8.4 & 5.9 \\
Latin America \& Caribbean & 5.6 & 3.9 \\
Southern Asia & 3.7 & 2.6 \\
Eastern Europe \& Central Asia & 2.5 & 1.8 \\
Sub-Saharan Africa & 1.5 & 1 \\
High & Income Level & 77.9 \\
Upper middle & 110.2 & 14.6 \\
Lower middle & 20.7 & 7.4 \\
Low & 10.5 & 0 \\
Municipal & 0.03 & 75.2 \\
Industry & Sector Use & 19.3 \\
Power Stations & 106.5 & 4.1 \\
Irrigation & 27.4 & 0.8 \\
Military & 5.8 & 0.3 \\
Other & 1.1 & 0.2 \\
\hline
\end{tabular}

Current global brine production stands at $141.5 \mathrm{~m}^{3} /$ day totalling 51.7 billion $\mathrm{m}^{3} /$ year. Table III categorizes brine production based on the geographical region, income level and sector use [6]. $80 \%$ of the total brine production is concentrated in middle east and north Africa (MENA), Asia and Pacific. This is not surprising as many of the countries in these areas experience localized or seasonal water scarcity, a situation made worse with climate emergency [13]. According to some estimates the global water withdrawals have doubled since the 1660's and there are no signs of slowing these trends. Taking into account that the world population in 2050 will grow to 9.8 billion and 11.2 billion in 
2100 [1] desalination will be an essential tool for ensuring water security for the future and innovation in brine management is critical to reduce its environmental impact and ensure economic sustainability [14].

\section{REJECT BRINE DISPOSAL STRATEGIES}

Effective brine management strategy takes into consideration the volume of the concentrate or brine, its chemical composition, geographical location, proximity to the disposal site or receiving area, applicable environmental regulations, capital, and operational costs. Concentrate disposal costs for high complexity desalination facilities can range from $2.5 \%$ to $2.7 \%$ of the total capital costs [15]. Table IV provides construction costs for different concentrate disposal strategies. Broadly the brine management strategies can be divided into three categories: brine minimization, direct disposal, and reuse applications.

TABLE IV: CONSTRUCTION COSTS FOR DIFFERENT CONCENTRATE DISPOSAL STRATEGIES [15]

\begin{tabular}{lc}
\multicolumn{1}{c}{ DISPOSAL STRATEGIES [15] } \\
\hline \multicolumn{1}{c}{ Concentrate Disposal Method } & $\begin{array}{c}\text { Disposal } \\
\text { Construction } \\
\text { Cost }\end{array}$ \\
(US\$/m3/day) *
\end{tabular}

Discharge strategies employed by selected desalinations facilities around the globe are listed in Table V. All the desalination plants listed in Table $\mathrm{V}$ are located near an open surface water body such as ocean and utilize surface water discharge to dispose reject brine. The desalination facilities located inland which do not have access to surface water body must rely on disposal options such as deep well injection, evaporation ponds or zero liquid discharge, which can be cost prohibitive as per Table IV. In such situations concentrate reuse applications such as biomass production through land application provide an opportunity for value added concentrate management, off-setting the operational costs.

Seawater Energy and Agricultural System (SEAS) is a demonstration project led by Sustainable Bioenergy Research Consortium (SBRC) based in United Arab Emirates (UAE). The main focus of this initiative is to lay the foundation for long term production of saltwater irrigated biomass in arid land for sustainable biofuel production. The project is designed to study the commercial viability of salt tolerant plant species also called halophyte derived jet fuel and bioenergy. Table 6 provides SBRC's projected aviation fuel production estimates from 2019-2032 utilizing the halophyte species Salicornia. Fig. 2 shows the general layout of the SEAS project. While the SEAS system focuses on monocropping other projects have evaluated the viability of using high conductivity effluent and saline water to cultivate biomass for fodder and human consumption [17], [18]. Study conducted in Brazil evaluated potential of using reject brine from inland desalination for fish farming, spirulina cultivation and irrigation of forage shrub and crops. The study experimented with various plants and vegetables and classified halophytes as the most convenient option when considering irrigation with desalination reject brine. The study also confirms that with land application of the reject brine progressive soil salinization remains an issue [19].

TABLE V: Selected Desalination Facilities With DiRect Discharge TO THE OCEAN [16], [11]

\begin{tabular}{|c|c|}
\hline Facility Name & Discharge Strategy \\
\hline $\begin{array}{l}\text { Tampa Bay } \\
\text { Seawater } \\
\text { Desalination, } \\
\text { Florida }\end{array}$ & $\begin{array}{l}\text { At full capacity, the RO plant generated } 19 \text { MGD of } \\
\text { concentrate volume which is twice as saline as the } \\
\text { surrounding waters in the near shore discharge } \\
\text { location. The concentrate is blended with } 1.4 \text { billion } \\
\text { gallons of cooling water achieving discharge salinity } \\
\text { which is } 1-1.5 \text { percent higher than the water in } \\
\text { Tamba Bay. A layout of the treatment plant is } \\
\text { provided in Appendix. }\end{array}$ \\
\hline $\begin{array}{l}\text { Antigua } \\
\text { desalination } \\
\text { facility, } \\
\text { Caribbean }\end{array}$ & $\begin{array}{l}\text { Desalination outfall extends } 300 \text { feet from the shore } \\
\text { and does not have diffusers. Concentrate exits } \\
\text { through an open pipe directly into the ocean, mixing } \\
\text { facilitated by kinetic energy and tidal movements. } \\
\text { Salinity within } 3 \mathrm{ft} \text { of the discharge point was } \\
\text { recorded to be } 45,00050,000 \mathrm{ppm} \text {. }\end{array}$ \\
\hline $\begin{array}{l}\text { Gold Coast } \\
\text { Desalination } \\
\text { Plant, Australia }\end{array}$ & $\begin{array}{l}\text { Concentrate of concentration } 67,000 \mathrm{ppm} \text { released } \\
\text { into the ocean through a multiple diffuser system. }\end{array}$ \\
\hline $\begin{array}{l}\text { Perth Seawater } \\
\text { Desalination } \\
\text { Plant, Australia }\end{array}$ & $\begin{array}{l}\text { Diffuser based outfall, } 500 \mathrm{~m} \text { off shore, has } 40 \text { ports } \\
\text { along the final } 200 \mathrm{~m} \text { at approx. } 0.5 \mathrm{~m} \text { from seabed } \\
\text { surface angled at } 60 \text { degrees. Design mixing ratio of } \\
\text { the diffuser system } 45: 1\end{array}$ \\
\hline $\begin{array}{l}\text { Alicante } 1 \\
\text { Desalination } \\
\text { Facility, Spain }\end{array}$ & $\begin{array}{l}\text { Located in turbulent tidally-influenced area exposed } \\
\text { to intense naturally occurring mixing, this allows for } \\
\text { a low mixing ration of } 1.5 \text { to } 5 \text { without measurable } \\
\text { environmental impact. }\end{array}$ \\
\hline $\begin{array}{c}\text { Javea } \\
\text { Desalination } \\
\text { facility, Spain } \\
\text { San Pedro del }\end{array}$ & $\begin{array}{l}\text { Discharge into an open channel, the concentrate in } \\
\text { the channel is diluted from } 69 \text { ppt to } 44 \text { ppt in a } 4: 1 \\
\text { mixing ratio. }\end{array}$ \\
\hline $\begin{array}{l}\text { Pintar } \\
\text { Desalination } \\
\text { Facility, Spain } \\
\end{array}$ & $\begin{array}{l}\text { Discharge through a diffuser approx. } 5 \mathrm{~km} \text { offshore } \\
\text { and } 38 \mathrm{~m} \text { deep. }\end{array}$ \\
\hline
\end{tabular}

TABLE VI: PROJECTED BIOFUEL PRODUCTION FROM SEAS PROJECT [17]

\begin{tabular}{cc}
\hline Year & Projected Biofuel production \\
\hline $2019-2021$ & $150-600 \mathrm{~L} /$ year \\
$2022-2026$ & $75,000-195,000 \mathrm{~L} /$ year \\
$2027-2031$ & $7,600,000-19,600,000 \mathrm{~L} / \mathrm{year}$ \\
$2032-$ Onwards & $75,700,000-194,500,000 \mathrm{~L} / \mathrm{year}$ \\
\hline
\end{tabular}

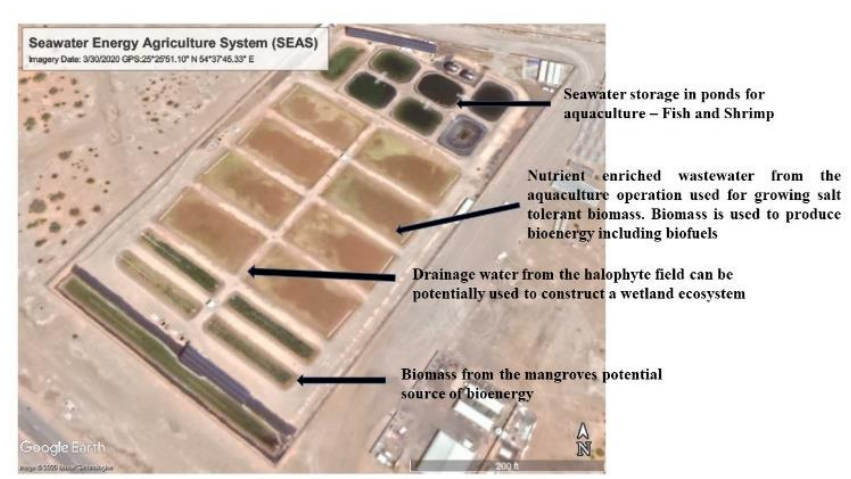

Fig. 2. General layout of the SEAS Project.

\section{NOVEl APPROACH FOR BIOMASS PRODUCTION}

Fig. 3 presents a novel conceptual layout for concentrate 
disposal utilizing integrated advanced agricultural techniques for multi-stage biomass production utilizing saline agriculture and aquaculture for micro and macroalgae. Cultivation with non-traditional irrigation water sources are being tested for different applications such as biofuel production, resilient agriculture and climate change adaptation [18], [19]. The layout is divided into three distinct zones or cells. Cell A provides storage for the effluent from the desalination treatment process. Depending on the type of desalination technology the waste stream in Cell A will include process concentrate, backwashing waste stream, clean in place waste stream, filter to waste stream etc. The cell will act as an equalization basin so that a consistent flow is achieved for the subsequent cells. Fig. 4 (a) and (b) provides a detailed set up of the subsequent stage Cell $\mathrm{B}$ which consists of tiered cells B1, B2 and B3 for the cultivation of salt tolerant or halophyte plant species. Irrigation water will be extracted from Cell $\mathrm{A}$ and can be applied either in series of parallel configuration as shown in Fig. 4 (a) and 4 (b). In series configuration the soil salinity and electrical conductivity of irrigation water increases linearly in subsequent cells which means that each successive cell is planted with halophyte species capable of tolerating and growing in elevated saline conditions.

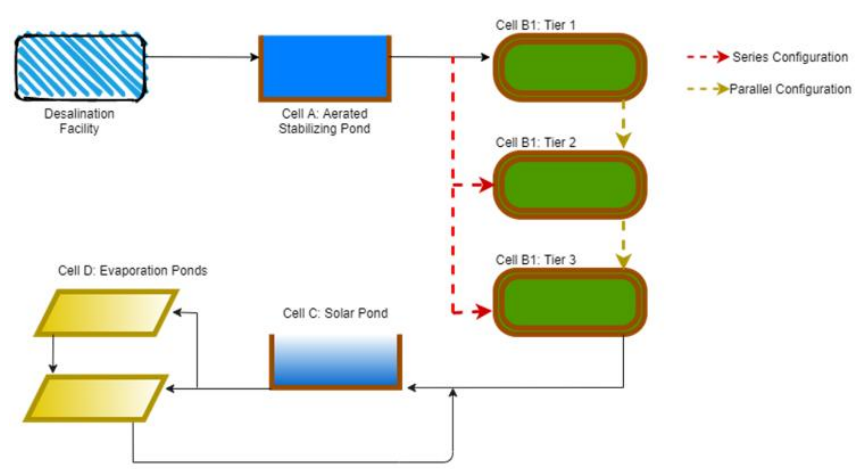

Fig. 3. Inland conceptual model for brine application for biomass production.

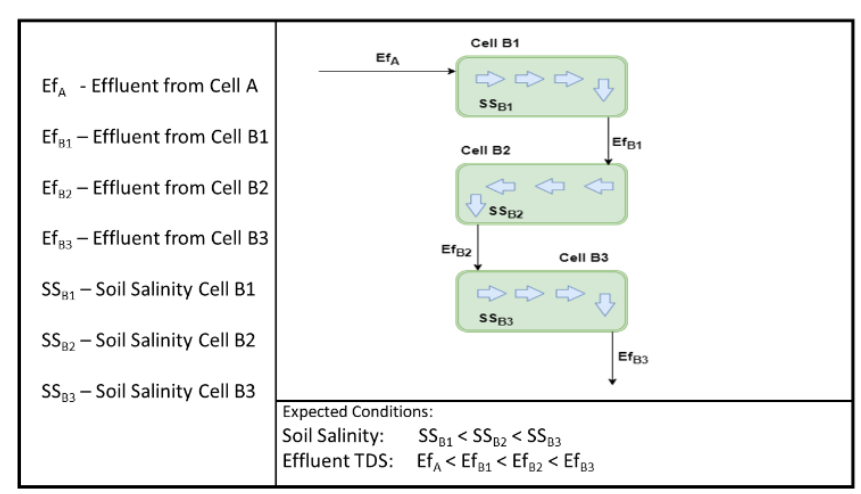

Fig. 4 (a). Cell B vegetation cultivation in series irrigation configuration.

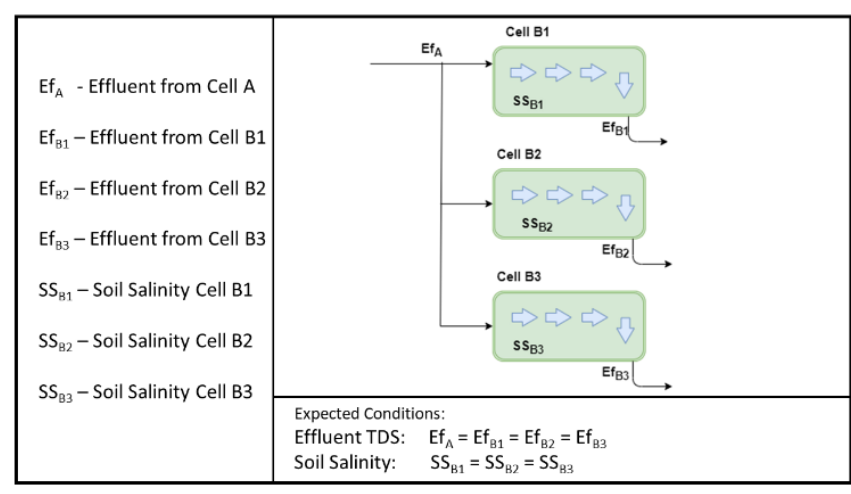

Fig. 4 (b). Cell B vegetation cultivation in parallel irrigation configuration.

Alternatively in parallel configuration all three cells are irrigated water with the same level of salinity. This allows for the soil salinity to remain consistent across all cells. Cell $\mathrm{C}$ is the last stage and can be configured for inland or onshore application as shown in Fig. 5 (a) and 5 (b). The saline and nutrient enhanced drainage water from Cell B1, B2 and B3 is transferred to Cell C. Fig. 5 (a) shows an onshore application which works in sync with the tidal fluctuations resulting in dilution of the effluent. Cell $\mathrm{C}$ can be utilized for the cultivation of macroalgae species. To ensure proper attenuation into the environment a wetland ecosystem can be design as shown in the detailed view of Fig. 5 (a). Inland configuration as shown in Fig. 5 (b) is similar to other integrated agricultural systems [19] and provides flexibility of utilizing disposal strategies such as evaporation ponds and deep well injection depending on local conditions and land availability. Under the right climate conditions, it may be possible to design Cell $\mathrm{C}$ as a solar pond for energy generation and offset some of the operational costs. Cell A as shown in Fig. 5 (b) can be used for macroalgae cultivation as another source of biomass.

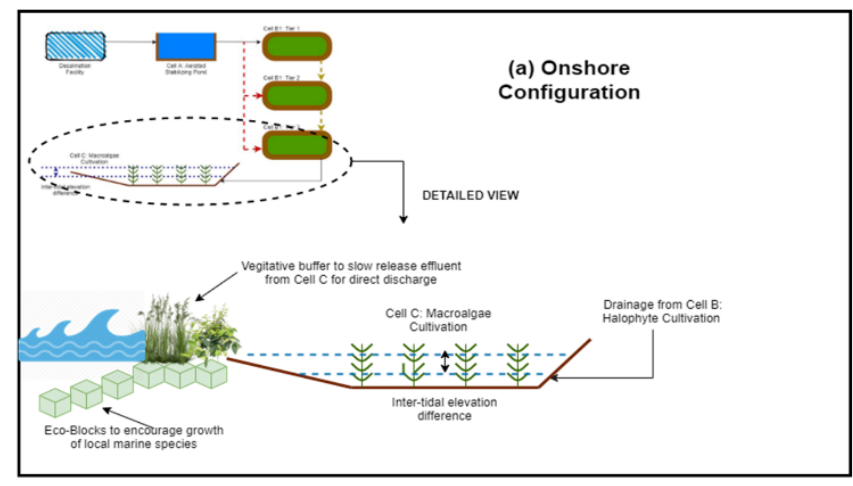

Fig. 5 (a). Detailed Cell C configuration for onshore application.

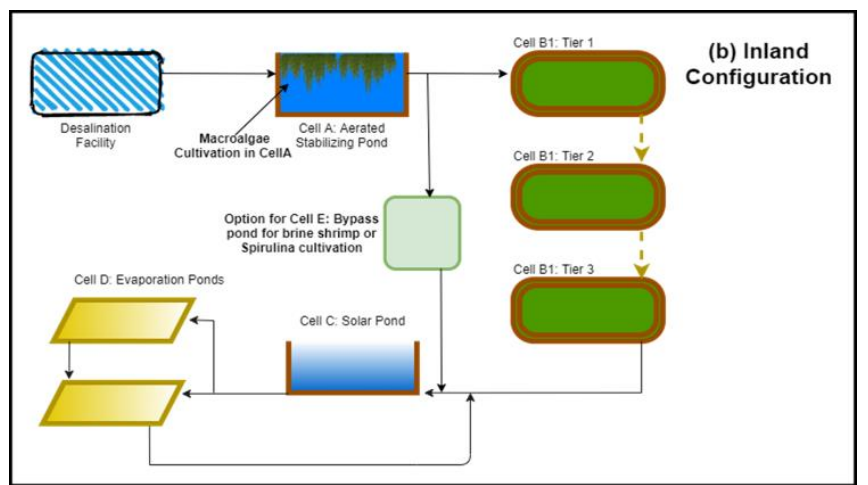

Fig. 5 (b). Cell C configuration for inland application. 


\section{DISCUSSION}

Desalination is being increasingly adopted to meet the rising consumer water demand and to hedge against climate change impacted such as droughts and irregular precipitation patterns [14]. As discussed in previous sections that the quality and quantity of the brine generated through the desalination process will largely depend on the type of desalination technology utilized. The disposal options available are limited by geographical location, local conditions and vary in cost as per Table 4. Spray irrigation and zero liquid discharge can offset the cost by producing economic valuable commodities as a byproduct. In terms of biomass production spray irrigation holds the most value. However, soil salinization is a long-term side effect which will limit its effectiveness over time and the high environmental cost incurred could offset any savings achieved through its application. In order to be sustainable biomass production using reject brine will need to adopt techniques such as crop rotation, maintaining soil health and enhancing biodiversity in the cultivation area [20]. As an emerging field biomass production using concentrate management has focused on monocropping [17], [19], [21]. However concerted effort needs to be made in order to further the research so that the sustainable farming practices can be incorporated. The novel approach proposed in this paper tries to mitigate existing constraints by proposing an enhanced operational strategy for concentrate management by leveraging local ecosystem components such salt tolerant plant species or halophytes. In addition, this approach takes multifaceted approach for multi-stage biomass production by combining agriculture, aquaculture and enriching local ecosystem by potential development of salt marshes and wetland. A pilot scale application can help evaluate the plant success rate for commercial bioprospecting and their ecological value for land restoration in areas impacted by sea level rise and salt water intrusion [22], [23].

The proposed reject brine re-use approach in this paper builds on the work by other researchers on value added concentrate management and enhances it by providing design flexibility to suite local conditions. For onshore applications naturally occurring salt tolerant species of plants with high economic value is recommended for biomass production. Inland application offers more flexibility in plant selection as the local climate conditions are the main determining factor. Cultivation of micro and macroalgae offer another opportunity for producing biomass of economic value in the form of biofuel, food, fertilizer and pharmaceutical applications [24], [25]. A variable irrigation protocol is proposed through the tired cells to facilitate the growth of different plant species capable of handling variable water and soil salinities. Two modes of operation are proposed series irrigation configuration linearly increasing soil salinity and parallel irrigation keeping the soil salinity normalized.

When the cells are operated in a series configuration as shown in Fig. 4 (a) it facilitates the growth of variety of salt tolerant plant species. When operated in parallel configuration the irrigation water quality is normalized over all cells which could help maintain soil salinization at a constant level. Series configuration will support different plant species capable for handling progressively higher soil salinities and the parallel configuration can be utilized for monocropping applications. Further experimentation is required to fully assess the design constraints for a pilot or full-scale application. Fig. 6 shows a lab scale experimental set up consisting of a concentrate storage tank, dosing pump, tiered halophyte cultivation pod, microalgae or macroalgae cultivation tank, compressor for aeration and recirculation line. The piping is configured to accommodate both parallel and series dosing protocols.

The halophyte cultivation pods are sloped so that the drainage water from irrigation can be transferred to the subsequent pods utilizing gravity flow. Sampling ports will be needed on the supply and drainage lines so that the water samples could be collected for analysis. A sampling port will also be needed on the macroalgae tank to monitor algae growth and take sample for water quality analysis. Following are recommended evaluation and research priorities for future work:

- Detailed assessment of the chemical composition of the desalination concentrate to determine its applicability for re-use applications.

- Determine the effluent characteristics from each stage of the multi-stage biomass production unit Fig. 6 for an in depth understanding of the water quality treatment level achieved of the effluent at each step.

- Sustainable application rates for irrigation water for each of the halophyte cultivation cells to minimize long term salinity accumulation of soil.

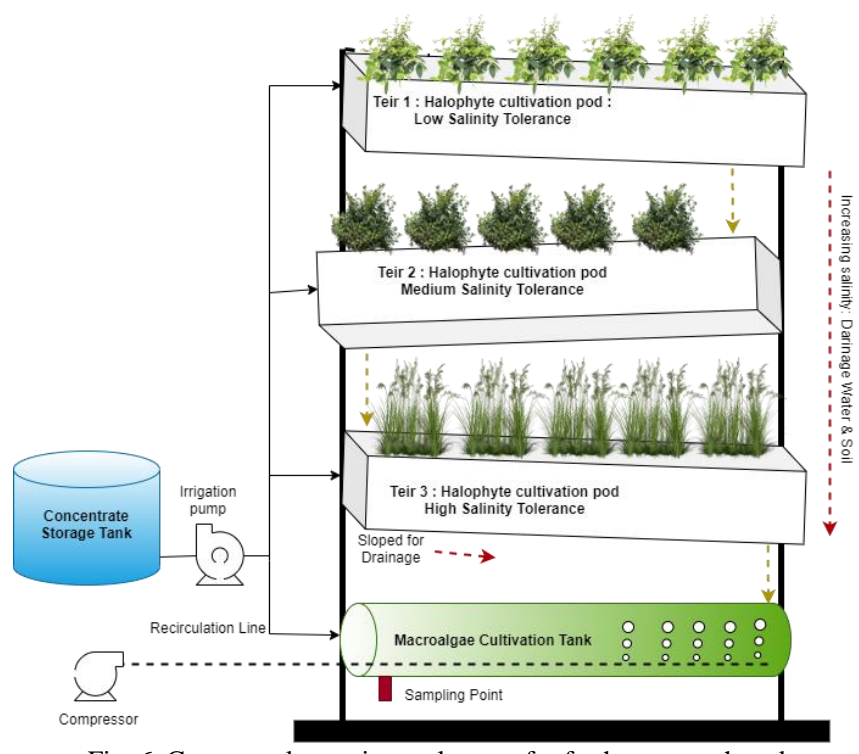

Fig. 6. Conceptual experimental set up for further research and experimentation.

- Classify halophyte species according to salinity tolerance of irrigation water and associated growth to maximize economic output.

- Classify macroalgae species according to salinity tolerance and toxicity absorption from the effluent growth environment.

- Complete a local field survey to locate the economically valuable salt tolerant plant species.

- Evaluate efficient agricultural techniques such as crop rotation to enhance land productivity and manage soil salinity.

- Evaluate intertidal mixing efficiency of the macro algae cultivation pond. 
- Evaluate the impact of natural conditions such as precipitation on mitigating soil salinity and impact on halophyte crop production.

- Evaluate optimum operational philosophy to alternate between series and parallel irrigation protocol to maximize soil and vegetation health.

- Evaluation of carbon capture potential of biomass generated by reject brine usage.

\section{CONCLUSION}

With the increasing world population traditional water resources will be under higher demand pressure. Many utilities will opt for desalination as a viable option to diversify their water supply and meet the increasing demand. Cost effective and environmentally conscious concentrate management will remain a priority for the desalination industry. Further research is needed to fully assess the re-use applications of desalination concentrate for biomass production. The proposed approach discussed in this paper builds on existing body of knowledge and offers improvements through novel operational characteristics to reduce the issue of soil salinization and monocropping. Integration of macro and microalgae as another source of biomass is proposed. Through the proposed experimental set up data gaps and design constraints can be identified for pilot or full-scale application.

\section{REFERENCES}

[1] M. Rosner Future Population Growth. Our World In Data, 2013. DOI: https://ourworldindata.org/future-population-growth.

[2] W.H. Thomas and D.R. Stephanie, Climate Change, Agriculture, and Poverty. Applied economic perspectives and policy, 2010. 32(3): p. 355-385.

[3] UnitedNations. Transforming our world: the 2030 Agenda for Sustainable Development A/RES/70/1. 2015; Available from: https://sustainabledevelopment.un.org/post2015/transformingourworl $\mathrm{d} /$ publication.

[4] J. Schewe, J. Heinke, D. Gerten, I. Haddeland, N.W. Arnell, D.B. Clark, R. Dankers, S. Eisner, B.M. Fekete, F.J. Colón-González, S.N Gosling, H. Kim, X. Liu, Y. Masaki, F.T. Portmann, Y. Satoh, T. Stacke, Q. Tang, Y. Wada, D. Wisser, T. Albrecht, K. Frieler, F. Piontek, L. Warszawski, and P. Kabat, Multimodel assessment of water scarcity under climate change. Proceedings of the National Academy of Sciences, 2014. 111(9): p. 3245.

[5] B. Richter, D. Abell, E. Bacha, K. Brauman, S. Calos, A. Cohn, C. Disla, S. O'Brien, D. Hodges, S. Kaiser, M. Loughran, C. Mestre, M. Reardon, and E. Siegfried, Tapped out: How can cities secure their water future? Water Policy Journal, 2013. 15: p. 335-363.

[6] E. Jones, M. Qadir, M.T.H. van Vliet, V. Smakhtin and S.-M. Kang, The state of desalination and brine production: A global outlook. Science of the Total Environment, 2019. 657: p. 1343-1356.

[7] N. Ghaffour, J. Bundschuh, H. Mahmoudi and M.F.A. Goosen, Renewable energy-driven desalination technologies: A comprehensive review on challenges and potential applications of integrated systems. Desalination, 2015. 356: p. 94-114.

[8] S. Panta, T. Flowers, P. Lane, R. Doyle, G. Haros and S. Shabala, Halophyte agriculture: Success stories. Environmental and experimental botany, 2014. 107: p. 71-83.

[9] M. Shakhawat Hossain, M. Arshad, L. Qian, H. Kächele, I. Khan, M. Din Il Islam, and M. Golam Mahboob, Climate change impacts on farmland value in Bangladesh. Ecological indicators, 2020. 112: p. 106181.

[10] S.Y. Teh and H.L. Koh, Climate change and soil salinization: impact on agriculture, water and food security. International Journal of Agriculture, Forestry and Plantation, 2016. 2: p. 1-9.

[11] N. Voutchkov, G. Kaiser, R. Stover, J. Lienhart and L. Awerbuch, Sustainable Management Of Desalination Plant Concentrate Desalination Industry Position Paper - Energy And Environment
Committee Of The International Desalination Association (IDA), in The International Desalination Association World Congress on Desalination and Water Reuse. 2019, International Desalination Association: Dubai, UAE.

[12] B. Ladewig, Desalination Concentrate Management by Bradley Ladewig, Benjamin Asquith, B. Asquith, SpringerLink, and Link, Editors. 2012, Berlin, Heidelberg : Springer Berlin Heidelberg : Imprint: Springer: Berlin, Heidelberg,ch 2. p. 7-10.

[13] M. Al-Rashed and A. Akber, Water security in the Gulf Cooperation Council (GCC) countries: challenges and opportunities. Proceedings of the International Association of Hydrological Sciences, 2015. 366: p. 119-120.

[14] A. Tubi and J. Williams, Beyond binary outcomes in climate adaptation: The illustrative case of desalination. Wiley interdisciplinary reviews. Climate change, 2021. 12(2): p. n/a.

[15] N. Voutchkov, Desalination Project Cost Estimating and Management. 2018, CRC press,ch 4. p. 65-91.

[16] TampaBayWater. Tampa Bay Seawater Desalination. 2020 [cited 2020 Febuary]; Available from: https://www.tampabaywater.org/tampabay-seawater-desalination.

[17] A. Rios. The Seawater Energy and Agriculture System. in International Civil Aviation Organization (ICAO) Seminar On Alternative Fuels 2017. 2017. Montreal, Quebec, Canada.

[18] Z. Paydar, S. Khan, M. Ali, R. Jamnani and J. Blackwell, Regional land suitability guidelines for SBC "Serial Biological Concentration" application, in CSIRO Land and Water Science Report 46/07. 2007: Canberra, ACT.

[19] A.S. Sánchez, I.B.R. Nogueira and R.A. Kalid, Uses of the reject brine from inland desalination for fish farming, Spirulina cultivation, and irrigation of forage shrub and crops. Desalination, 2015. 364: p. 96107.

[20] S. Ouda, A. Zohry and T. Noreldin, Crop rotation maintains soil sustainability, in Crop Rotation. 2018, Springer55-76.

[21] D. Soliz, E.P. Glenn, R. Seaman, M. Yoklic, S.G. Nelson and P. Brown, Water consumption, irrigation efficiency and nutritional value of Atriplex lentiformis grown on reverse osmosis brine in a desert irrigation district. Agriculture, ecosystems \& environment, 2011. 140(3-4): p. 473-483.

[22] I. Md. Anowarul, S. Paul Kumar and H. Md. Zahidul, Agricultural vulnerability in Bangladesh to climate change induced sea level rise and options for adaptation: a study of a coastal Upazila. Journal of agricolture and environment for international development, 2015. 109(1): p. 19-39.

[23] E.A. Ury, X. Yang, J.P. Wright and E.S. Bernhardt, Rapid deforestation of a coastal landscape driven by sea level rise and extreme events. Ecological applications, 2021: p. e2339-e2339.

[24] A.K. Parida, A. Kumari, J. Rangani and M. Patel, Halophytes and climate change : adaptive mechanisms and potential uses/editors: Mirza Hasanuzzaman, Sergey Shabala, Masayuki Fujita., in Halophyte and Climate Change, M. Hasanuzzaman, S. Shabala, and M. Fujita, Editors. 2018,Halophytes: Potential Resources of Coastal Ecosystems and their Economic, Ecologiocal and Bioprospecting Significance. p. 287-312.

[25] B.K. Tiwari and D.J. Troy, Seaweed sustainability-food and nonfood applications, in Seaweed sustainability. 2015, Elsevier1-6. 